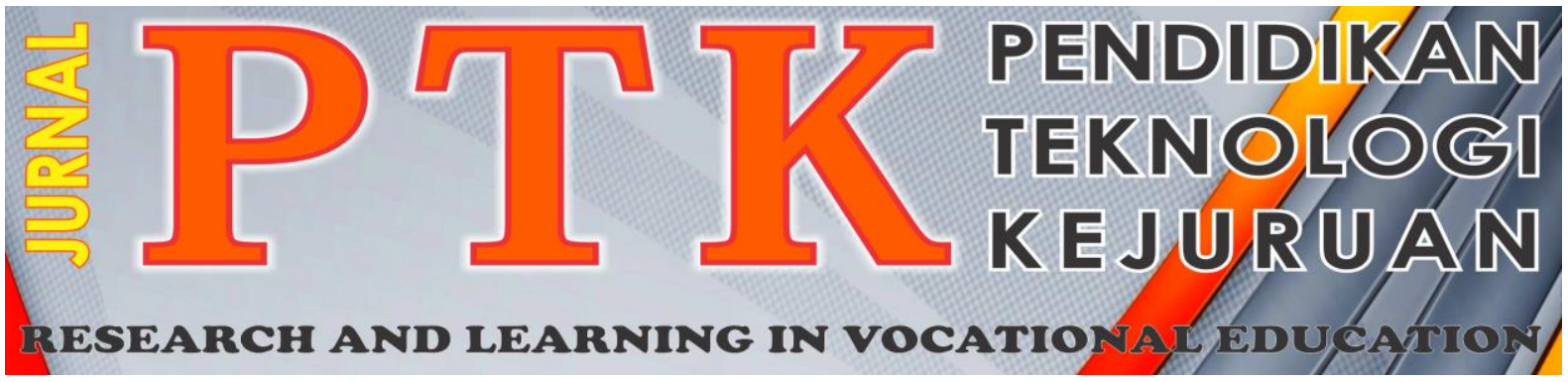

Vol. 1, No. 2 Mei 2018

P-ISSN: 2621 - 3273

E ISSN: 2621 - 1548

\title{
KORELASI KEMAMPUAN MENYUSUN PARAGRAF DAN MOTIVASI BERPRESTASI SISWA DENGAN KETERAMPILAN MENULIS LAPORAN
}

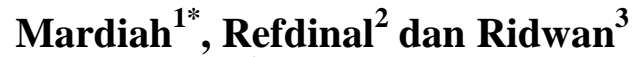 \\ SMK Negeri 1 Lahat ${ }^{1}$, Universitas Negeri Padang ${ }^{2,3}$ \\ "Corresponding author, e-mail: mardiah@gmail.com
}

\begin{abstract}
Abstrak - Penelitian ini bertujuan untuk mengungkapkan korelasi kemampuan menyusun paragraf dan motivasi berprestasi siswa dengan keterampilan menulis laporan. Penelitian ini merupakan penelitian deskriptif korelasional. Populasi penelitian ini adalah seluruh siswa kelas XI Jurusan Teknik otomotif SMK Negeri 1 Lahat dengan jumlah siswa 125 siswa. Ukuran sampel ditentukan dengan menggunakan rumus Slovin dengan kelonggaran penelitian yang digunakan dalam pengambilan sampel penelitian $5 \%$ sehingga jumlah sampel yang dalam penelitian ini sebanyak 95 orang. Instrumen yang digunakan untuk mengumpulkan data penelitian adalah tes dan questionare. Penelitian ini menggunakan analisis data kuantitatif dengan menggunakan metode statistik berupa korelasi dan regresi yang akan digunakan untuk pengujian hipotesis-hipotesis penelitian. Hasil penelitian ini membuktikan hubungan positif kemampuan menyusun paragraf terhadap kemampuan menulis laporan siswa. Semakin baik kemampuan menyusun paragraf seorang siswa maka akan semakin baik pula kemampuan menyusun laporannya, dan begitu sebaliknya. Berdasarkan analisis data yang ditemukan bahwa terdapat hubungan posotif yang signifikan antara variabel motivasi berprestasi dengan kemampuan menyusun laporan siswa. Hal ini mejelaskan semakin tinggi motivasi berprestasi seseorang maka laporan yang dibuatnya akan memiliki kualitas yang baik pula dan begitu sebaliknya. Semakin kurang motivasi berprestasi siswa maka akan semakin rendah pula kualitas laporan yang dihasilkan.
\end{abstract}

Kata kunci: Kemampuan menyusun paragraph, motivasi berprestasi, kemampuan menulis laporan.

Abstract-This study aims to link students' understanding and organization with report writing skills. This research is a correlational descriptive research. The population of this study is all students of class XI Automotive Engineering Department SMK Negeri 1 Lahat consisting of 125 students. Sample size by using Slovin formula with research leeway which in sampling research $5 \%$ of sample amount in this research counted 95 people. The instruments used to collect research data are test and questionare. This study uses quantitative data using statistical methods and regression that will be used for testing research hypotheses. The results of this study prove the positive relationship of the ability to arrange paragraphs to the ability to write student reports. The better the ability to compose the students the better the ability to prepare the report, and so on the contrary. The analysis of data found that has a significant relationship between achievement motivation variables with the ability to prepare student reports. This explains the higher motivation of achievement someone then the report he made will have a good quality and very different. The less motivation of student achievement, the faster the quality of the report will be produced.

Keywords: Ability to arrange paragraph, achievement motivation, writing skill report 


\section{Pendahuluan}

Teknologi modern saat ini menuntuk setiap individu harus mampu baca tulis guna mengikuti perkembangan zaman yang sedang berkembang. Interaksi antara individu membutuhkan tulisan untuk melakukan komuniasi. Dikatakan oleh [1] kurang mampunya seseorang menulis merupakan permasalahan yang serius dalam menjalani kehidupan. Keterampilan menulis tidak didapat dengan begitu saja, tetapi membutuhkan usaha dan kerjakeras berbagai kalangan utuk menyampaikan pembelaajran yang mana ini menajadi tugas pengajar (guru). Berdasarkan permasalahan ini terlihat sangat pentingnya pembelajaran menulis khususnya dalam amta pelajaran Bahasa Indonesia di SMA/SMK sangat membuthkan perhatian yang serius.

Mendefinisikan menulis sebagai suatu kegiatan penyampaian pesan dengan menggunakan bahasa tulis sebagai alat atau medianya [2]. Menulis merupakan salah satu media untuk berkomunikasi, dimana anak dapat menyampaikan makna, ide, pikiran dan perasaannya melalui untaian kata-kata yang bermakna [3]. [4] Memaparkan bahwa menulis merupakan suatu keterampilan berbahasa, yaitu kegiatan komunikasi dengan menurunkan atau melukiskan lambang-lambang grafik bahasa yang dipahami oleh seseorang secara tidak langsung dan tanpa bertatap muka agar pembaca dapat memahami pula bahasa dan gambaran grafik tersebut. Pemaparan mengenai definisi menulis secara lebih singkat dan jelas diungkapkan [5] menulis bukan hanya berupa melahirkan pikiran atau perasaan saja, melainkan juga merupakan pengungkapan ide, pengetahuan, ilmu dan pengalaman hidup seseorang dalam bahasa tulis. Itu berarti bahwa murid-murid membutuhkan banyak praktik dalam menguasai ketrampilan menulis agar dapat menghasilkan teks yang bagus. Berdasarkan uraian di atas dapat disimpulkan bahwa keterampilan menulis adalah kegiatan komunikasi untuk menyampaikan pesan yang berisi pikiran, perasaan, ide, pengetahuan, dan pengalaman seseorang melalui bahasa tulis, salah satunya dalam bentuk paragraf.

Keterampilan menulis menghendaki adanya pemahaman mengenai lambang atau simbol simbol visual serta aturan dalam menulis, khususnya menyangkut masalah ejaan. Penulis juga harus kemampuan berfikir secara logis agar mampu mengemukakan ide, gagasan yang dapat dipahami oleh semua orang. Ide yang dikemukan dalam bentuk tulisan harus memiliki skema dan tata autran. Agar pesan yang disampaikan melalui karya tulis dapat dipahami oleh pembaca, meka penulis harus menuangkan gagasannya ke dalam bahasa yang tepat, teratur, dan lengkap.

Fenomena yang ditemukan dari hasil pengamatan yang penulis lakukan selama ini di SMK Negeri 1 Lahat terlihat pada karya tulis siswa yang masih jauh dari harapan. Hal itu terlihat pada: (1) rendahnya kemampuan siswa dalam memilih dan menata gagasan dengan pikiran yang logis dan sistematis; (2) rendahnya kemampuan siswa dalam menuangkan gagasannya ke dalam bentuk-bentuk tuturan bahasa Indonesia sesuai dengan kaidah-kaidah bahasa Indonesia; (3) rendahnya kemampuan siswa menuliskan hasil tulisannya sesuai dengan Pedoman Umum Ejaan Bahasa Indonesia Yang Disempurnakan (EYD); dan (4) rendahnya kemampuan siswa memilih ragam bahasa Indonesia sesuai dengan konteks komunikasi.

Hal ini tergambar dari nilai keterampilan siswa dalam menyusun laporan, ternyata hanya sebagian siswa yang mampu menyusun laporan sesuai dengan prosedur yang telah ditetapkan. Contohnya pada siswa Kelas XI. TKR.1 hanya 17 siswa yang memperoleh nilai di atas KKM yaitu 75, Kelas TKR.2 sebanyak 16 siswa, sedangkan kelas XI TSM 1 hanya 13 siswa dan kelas XI TSM2 hanya 15 siswa yang mampu menyusun laporan dengan baik.

Penerapan penggunaan Bahasa Indonesia tulis yang masih kurang dikuasi siswa SMK membuat siswa kesulitan dalam menyusun karya tulis baik berupa laporan ataupun karya tulis lainnya. Aspek-aspek kesalahan itu meliputi bidang ejaan, diksi, kalimat (kohesi-koherensi, kesejajaran, dan keekonomisan), dan pengorganisasian paragraf. Kesalahan-kesalahan itu pada umumnya merupakan kesalahan yang tergolong dalam kesalahan penerapan kaidah yang tidak sempurna Berikut ini adalah nilai hasil belajar Bahasa Indonesia Siswa TKR dan TSM kelas XI sebagai berikut:

TABEL 1 NILAI BAHASA INDONESIA SEMESTER II TKR DAN TSM KELAS XI DI SMKN 1 LAHAT

\begin{tabular}{ccccc}
\hline Kelas & $\begin{array}{c}\text { Jumlah } \\
\text { siswa }\end{array}$ & $\begin{array}{c}\text { Rata- } \\
\text { rata }\end{array}$ & Tuntas & $\begin{array}{r}\text { Tidak } \\
\text { Tuntas }\end{array}$ \\
\hline $\begin{array}{c}\text { XI.TKR. } \\
1\end{array}$ & 29 & 70,74 & 17 & 12 \\
$\begin{array}{c}\text { XI. } \\
\text { TKR.2 } \\
\text { XI. }\end{array}$ & 39 & 68.82 & 16 & 23 \\
$\begin{array}{c}\text { TSM.1 } \\
\text { XI. }\end{array}$ & 31 & 63.57 & 13 & 18 \\
TSM.2 & 26 & 67.32 & 15 & 11 \\
\hline
\end{tabular}




$\begin{array}{llll}\text { Jumlah } & 125 & 61 & 64\end{array}$

Sumber. Guru Bahasa Indonesia XI TKR dan TSM Kelas XI SMKN 1 Lahat

Berdasarkan tabel di atas dapat disimpulkan bahwa masih banyak siswa jurusan TSM dan TKR kelas XI SMKN 1 Lahat memperoleh nilai di bawah KKM yang ditetapkan oleh sekolah. Adapun siswa yang tuntas sebanyak 61 orang, sedangkan yang tidak tuntas sebanyak 64 orang. Hal ini membuktikan bahwa kemampuan siswa dalam menyusun paragraf masih kurang, sehingga hal ini berdampak terhadap keterampilan siswa dalam menulis laporan.

Menyatakan bahwa laporan berasal dari bahasa Latin reportare, membawa kembali dokumen tertulis yang disusun sebagai hasil dari prosedur untuk menjelaskan informasi [6]. Pertelaan (daftar perincian tentang suatu hal) formal tentang fakta, catatan atau hasil dari sesuatu dengan cara sistematis. Laporan adalah segala sesuatu yang dilaporkan. Penulisan laporan adalah penyampaian informasi yang bersifat faktual tentang sesuatu dari satu pihak kepada pihak lain [7]. Dengan kata lain, penulisan laporan menyangkut tiga hal, yaitu: (1) apa yang dilaporkan; (2) siapa yang melaporkan; dan (3) kepada siapa laporan itu disampaikan. Berdasarkan berbagai pengertian tentang laporan dapat disimpulkan bahwa laporan merupakan suatu bentuk informasi yang disampaikan kepada orang lain atau suatu instansi atau badan lain dalam bentuktertulis dengan menggunakan sistematika tertentu yang menguraikan atau membahas sebuah masalah yang dihadapi disertai bukti-bukti dan fakta-fakta yang nyata.

Selanjutnya pengertian menulis laporan dapat diterjemahkan sebagai ketelatenan seorang siswa dalam menginformasikan dengan bagaimana ia mendayagunakan semua fungsi mental kognitifnya untuk menuangkan buah pikiran secara teratur dan terorganisasi ke dalam sebuah karangan yang berbentuk laporan. Dalam kegiatan menulis diperlukan suatu keterampilan dalam pengorganisasian ide-ide ke dalam bentuk tulisan yang runtut dan padu. Dalam tulisan tersebut harus diperhatikan kaidah-kaidah penulisannya.

Tulisan yang runtut dan padu harus terdapat unsur seperti: singkat, tepat, jelas dan memiliki logika yang benar., serta koheren. Artinya, sebuah tulisan tidak perlu menambahkan hal yang tidak perlu diluar gagasan dalam sebuah tulisan, tidak mengulang-ulang yang sudah dijelaskan (redudant), tidak mempunyai arti ganda (ambiguous, dan paparan ide pokok didukung oleh penjelasan dan simpulan. Ide-ide pokok tersebut saling berkaitan, mendukung ide utama sehingga seluruh bagian tulisan merupakan kesatuan yang saling berhubungan atau bertautan (coherence) [8]. Sesuai dengan masalah penelitian yang diangkat, dalam kajian ini, kegiatan menulis diarahkan pada menulis laporan. Oleh karena itu, perlu disinggung perihal laporan.

Kemampuan menyusun paragraf adalah kesanggupan siswa dalam menyusun rangkaian kata menjadi kalimat yang meruapakan syarat kelengkapan dan kesatuan dalam tulisan. Kemampuan tersebut terukur dengan indikator: (1) kesesuaian ide dengan isi yang disampaikan (kesatuan gagasan), (2) organisasi isi, meliputi: komposisi tulisan pada paragraf (koherensi dan kohesifan antar kalimat), keruntutan: (3) ketepatan penggunaan tata bahasa dan pola kalimat (struktur kalimat): (4) ketepatan penggunaan kata /istilah (diksi): dan (5) ketepatan penggunaan ejaan dan tanda baca.

Menyusun laporan tentunya berkaitan dengan tingkat capaian prestasi. Motivasi berprestasi berhubungan dengan pola tindakan dan perasaan yang berkaitan dengan kerja keras atau perjuangan yang bertujuan untuk mencapai prestasi yang tinggi termasuk di dalamnya prestasi membaca pemahaman. Motivasi berprestasi merupakan salah satu faktor yang cukup besar pengaruhnya terhadap kemampuan membaca pemahaman. Sebagaimana pernyataan [9] kerapkali kegagalan dalam membaca terjadi karena rendahnya motivasi. Seseorang yang memiliki motivasi berprestasi serta giat membaca tanpa ada indicator lain yang mempengaruhi, sedangkan yang memiliki motivasi rendah akan enggan membaca.

Seseorang yang memiliki motivasi berprestasi sebagai suatu kebutuhan dapat menjadi dorongan untuk mencapai tujuan. Dalam motivasi berprestasi terdapat tiga tipe tujuan, yakni (1) tujuan penguasaan yang berfokus pada kompetisi atau penguasaan seperangkat pengetahuan atau ketrampilan baru, (2) tujuan penampilan yang berfokus pada pencapaian standar normatif, melakukan suatu hal secara lebih baik daripada orang lain, dan (3) tujuan sosial yang berfokus pada hubungan antar manusia. Dari sini terlihat bahwa ada keterkaitan anatara motivasi berprestasi dan keterampilan dalam membuat laporan. Dalam pembelajaran di SMK laporan merupakan tugas penting sebagai bahan observasi kegiatan.

Motivasi yang diharapkan dalam dunia pendidikan adalah motivasi berprestasi. Di sini, individu atau peserta didik diharapkan 
mempunyai motivasi berprestasi yang tinggi agar dapat mewujudkan tujuan pendidikan yang sesungguhnya. Motivasi berprestasi adalah motivasi yang berhubungan dengan pencapaian beberapa standar kepandaian atau standar keahlian [10]. Standar inilah yang akan dijadikan alat ukur atas motivasi tersebut. Motivasi berprestasi merupakan salah satu faktor yang cukup mempengaruhi dalam pencapaian hasil belajar individu atau siswa. Berdasarkan pendapat yang telah dikemukakan oleh beberapa ahli tersebut, dapat diambil kesimpulan bahwa motivasi berprestasi adalah dorongan yang muncul dari dalam diri seseorang untuk memenuhi kebutuhannya (kebutuhan berprestasi) guna mencapai tujuan tertentu berupa pencapaian preestasi setinggi mungkin dengan menggunakan standar keunggulan. Motivasi terbentuk atas dasar kebutuhan hidup manusia, baik kebutuhan fisiologi, kebutuhan keamanan, kebutuhan berprestasi dan sebagainya. Jika kebutuhan ini dapat dipenuhi oleh individu dengan baik maka tujuan yang diharapkan tentunya juga akan dapat tercapai dan terealiasai dengan baik juga.

Berdasarkan uraian tersebut, maka penulis melakukan penelitian tentang Hubungan antara Kemampuan Menyusun Paragraf dan Motivasi Berprestasi dengan Keterampilan Menulis Laporan Siswa di SMK Negeri 1 Lahat.

Tujuan penelitian yang dilakukan adalah untuk:

1. Hubungan kemampuan menyusun paragraf dengan keterampilan menulis laporan siswa SMK Negeri 1 Lahat.

2. Hubungan antara motivasi berprestasi dengan keterampilan menulis laporan siswa SMK Negeri 1 Lahat.

3. Hubungan antara kemampuan menyusun paragraf dan motivasi berprestasi secara bersama - sama dengan keterampilan menulis laporan siswa SMK Negeri 1 Lahat.

\section{Metode}

\section{A. Jenis Penelitian}

Jenis penelitian yang digunakan dalam penelitian ini adalah deskriptif korelasional. Jenis penelitian deskriptif korelasional ini dapat dipakai untuk mendeteksi sejauh mana variasi-variasi pada suatu faktor berkaitan dengan variasi-variasi pada satu atau lebih faktor lain berdasarkan pada koefisien korelasi [11]. Metode penelitian ini merupakan salah satu bentuk penelitian deskriptif yang bertujuan untuk mendeskripsikan variabelvariabel penelitian dan menvarisi hubungan antara satu variabel dengan variabel yang dapat dinyatakan dengan koefisien korelasi. Variabel bebas penelitian ini adalah kemampuan menyusun paragraf $\left(\mathrm{X}_{1}\right)$ dan motivasi berprestasi $\left(\mathrm{X}_{2}\right)$, sedangkan yang menjadi variabel terikat adalah kemampuan menyusun laporan (Y).

\section{B. Populasi dan sampel penelitian}

\section{Polulasi}

Populasi penelitian ini ialah seluruh siswa kelas XI Jurusan Teknik Otomotif SMK Negeri 1 Lahat yang terdiri dari 4 kelas dengan jumlah total siswa 125 siswa.

\section{Sampel}

Dalam penelitian ini ukuran sampel ditentukan dengan menggunakan rumus Slovin. Persentase kelonggaran penelitian yang digunakan dalam pengambilan sampel penelitian ini 5\%.

$$
\begin{aligned}
& n=\frac{125}{1+125(0,05)^{2}} \\
& n=91,54 \text { (dibulatkan menjadi } 95 \text { orang) }
\end{aligned}
$$

Berdasarkan perhitungan di atas, dari jumlah populasi 125 siswa yang dijadikan sampel sebanyak 95 siswa. Jumlah sampel yang diambil dalam penelitian ini dihitung sebagai berikut:

$$
\frac{29}{125} \times 95=22,42
$$

$$
\begin{aligned}
& \text { X1.TKR1 = (dibulatkan menjadi } 22 \text { orang) } \\
& \frac{39}{125} \times 95=30,15 \\
& \frac{31}{125} \times 95=23,42
\end{aligned}
$$

Tabel 2. Sampel penelitian

\begin{tabular}{clc}
\hline No. & \multicolumn{1}{c}{$\begin{array}{c}\text { Populasi Menurut } \\
\text { Kelas }\end{array}$} & Jumlah Siswa \\
\hline 1. & XI.TKR.1 & 22 Siswa \\
2. & XI. TKR.2 & 30 Siswa \\
3. & XI. TSM.1 & 24 Siswa \\
4 & XI. TSM.2 & 20 Siswa \\
\hline & Jumlah & 95 Siswa \\
\hline
\end{tabular}

\section{Jenis dan Sumbar Data}

Dilihat dari cara perolehannya, maka penelitian ini menggunakan dua sumber yaitu: 
1. Data primer, yaitu data yang langsung diperoleh dari subjek dengan memberikan daftar pertayaan kepada siswa.

2. Data sekunder, yaitu data yang didapatkan dari pihak lain, tidak langsung dari subjek penelitian. Dalam hal ini data yang didapat mengenai jumlah siswa Teknik Kendaraan Ringan kelas XI di SMKN 1 Lahat.

\section{Teknik Pengumpulan Data}

Pengumpulan data tentang keterampilan menulis laporan dan kemampuan menyusun paragraf digunakan dengan teknik tes. Adapun tes yang digunakan untuk mengukur keterampilan menulis laporan dan kemampuan menyusun paragraf berbentuk tes esai dengan memberi tugas mengarang/menyusun paragraf kepada siswa. Sementarai itu, data motivasi berprestasi dikumpulkan dengan teknik nontes yang berupa pemberian angket motivasi berprestasi pada responden (sampel) penelitian. Angket adalah sejumlah pertanyaan tertulis yang digunakan untuk memperoleh informasi dari responden dalam arti laporan tentang pribadinya, atau hal-hal yang diketahui [12].

\section{E. Instrumen Penelitian}

Instrumen yang digunakan untuk mengumpulkan data penelitian adalah tes dan questionare. Untuk data kemampuan menyusun paragraf diperoleh dari nilai siswa berdasarkan tes pengembangan paragraf, sedangkan untuk data motivasi berprestasi diperoleh melalui kuesionare atau angket yang berisi sejumlah pertanyaan dan pernyataan yang akan diisi oleh sampel penelitian.

\section{F. Uji Coba penelitian}

Uji coba instrumen dilakukan pada responden yakni siswa SMK Negeri 1 Lahat sebanyak 30 orang. Sampel siswa SMK Negeri 1 Lahat diasumsikan memiliki karakteristik yang sama. Uji coba dilakukan untuk mengukur tingkat validitas (kesahihan) dan reliabilitas (keterandalan) instrumen.

\section{G. Teknik Analisis Data}

Penelitian ini menggunakan analisis data kuantitatif dengan menggunakan metode statistik berupa korelasi dan regresi yang akan digunakan untuk pengujian hipotesis-hipotesis penelitian. Setelah itu dilakukan pembahasan mengenai hasil analisis statistik tersebut. Pembahasan ini ditujukan memberikan interpretasi terhadap hasil analisis yang dilakukan.

\section{Deskripsi Data}

Diskripsi data disusun berdasarkan Mean ideal (Mi) dan standar deviasi (Sdi). Untuk tabel distribusi frekuensi data dibuat dengan cara menentukan kelas interval dari masing-masing variabel berpedoman pada aturan sturges sebagai mana yang dijelaskan oleh Riduwan [13].

\section{Uji Prasyarat Data}

Uji persyaratan analisis dimaksudkan untuk menguji apakah data yang dikumpulkan memenuhi syarat untuk dianalisis dengan statistik. Sesuai tujuan penelitian teknik analisis yang digunakan adalah analisis regresi ganda. Untuk keperluan tersebut harus terpenuhi asumsi bahwa data harus berdistrubusi normal dan hubungan antara variabel bebas dengan terikat harus linier.

\section{HASIL DAN PEMBAHASAN}

Hasil penelitian ini menemukan adanya hubungan positif yang signifikan antara kemampuan menyusun paragraf dan motivasi berprestasi terhadap keterampilan menulis laporan pada siswa di SMK Negeri 1 Lahat. Hasil uji persyaratan analisis yaitu normalitas dan linearitas menunjukkan bahwa data dapat diuji dengan regresi.

\section{A. Hubungan kemampuan menyusun paragraf terhadap keterampilan menulis laporan}

Berdasarkan hasil analisis pada hipotesis pertama, nilai korelasi antara variabel kemampuan menyusun paragraf dengan kemampuan menulis laporan adalah 0,491. Adapun kekuatan hubungannya anatara variabel kemampuan menyusun paragraf terhadap variabel kemampuan menulis laporan berada pada interval $0,30-0,49$ yang artinya memiliki hubungan mederat atau cukup tapi pasti.

Hasil analisis regresi sederhana membuktikan bahwa kemampuan menyusun paragraf berkontribusi secara signifikan terhadap kemampuan menulis laporan siswa. Hasil analisis didapatkan $\mathrm{F}_{\text {hitung }}=29,607$ dengan signifikansi $0,000<0,05$, dimana $\mathrm{Ha}$ diterima artinya kemampuan menyusun paragraf berkontribusi secara signifikan terhadap keterampilan menulis laporan. Berdasarkan hasil analisis diperoleh pula nilai koefisien penentu (KP) sebesar 24,1\%. Dari nilai koefisien determinasi tersebut dapat dijelaskan bahwa besarnya pengaruh atau 
kontribusi kemampuan menyusun paragraf terhadap kemampuan menulis laporan siswa adalah $24,1 \%$ dan selebihnya yaitu $75,9 \%$ dipengaruhi faktor lain diluar kemampuan menyusun paragraf yang tidak dikaji dalam penelitian ini.

Paragraf merupakan suatu kumpulan dari kesatuan pikiran yang kedudukannya lebih tinggi serta lebih luas dari kalimat. Dapat pula diartikan paragraf adalah bagian dari sebuah karangan yang terdiri dari beberapa kalimat, yang berisikan tentang informasi dari penulis untuk pembaca dengan pikiran utama sebagai pusatnya dan juga pikiran penjelas sebagai pendukungnya. Paragraf terdiri dari beberapa kalimat yang berhubungan antara satu dengan yang lain dalam suatu rangkaian yang menghasilkan sebuah informasi.

Paragraf yang tersusun sesuai dengan kidah penulisan yang benar akan berfungsi sebagai alat bantu penulis ataupun pembaca. Kumpulan dari kalimat akan memungkinkan pengarang mengembangkan jalan pikirannya secara sistematis pula. Kalimat yang tersusun secara sistematis itu sangat memudahkan untuk menelusuri dan memahami jalan pikiran seseorang. Untuk menciptakan paragraf yang baik, sebaiknya penulis harus memahami syaratsyaratnya. [14] Menjelaskan dalam penyusunan paragraf yang baik harus memperhatikan: 1) kesatuan, 2) kepaduan, dan 3) kelengkapan.

Kemampuan menyusunan paragraf dalam penulisan laporan sangatlah penting. Kalimat yang baik dan tersusun dalam paragraf akan menyampaikan informasi mengenai isi dan proses yang dijelaskan dalam sebuah laporan. Hasil penelitian ini membuktikan hubungan positif kemampuan menyusun paragraf terhadap kemampuan menulis laporan siswa. Semakin baik kemampuan menyusun paragraf seorang siswa maka akan semakin baik pula kemampuan menyusun laporannya, dan begitu sebaliknya.

\section{B. Hubungan motivasi berprestasi terhadap kemampuan menulis laporan siswa}

Berdasarkan hasil analisis pada hipotesis kedua, nilai korelasi antara variabel motivasi berprestasi dengan kemampuan menulis laporan adalah 0,386 . Adapun kekuatan hubungannya anatara variabel motivasi berprestasi terhadap variabel kemampuan menulis laporan berada pada interval $0,30-0,49$ yang artinya memiliki hubungan mederat atau cukup tapi pasti.

Hasil analisis regresi sederhana membuktikan bahwa motivasi berprestasi berkontribusi secara signifikan terhadap kemampuan menulis laporan siswa. Hasil analisis didapatkan $\mathrm{F}_{\text {hitung }}=16,306$ dengan signifikansi $0,000<0,05$, dimana $\mathrm{Ha}$ diterima artinya motivasi berprestasi memiliki hubungan secara signifikan terhadap keterampilan menulis laporan. Kemudian besarnya sumbangan motivasi berprestasi terhadap kemampuan menulis laporan adalah $14,89 \%$ dan selebihnya yaitu $85,02 \%$ dari kemampuan menulis laporan siswa dipengaruhi faktor lain diluar motivasi berprestasi yang tidak dikaji dalam penelitian ini.

Motivasi yang diharapkan dalam dunia pendidikan adalah motivasi berprestasi. Di sini, individu atau peserta didik diharapkan mempunyai motivasi berprestasi yang tinggi agar dapat mewujudkan tujuan pendidikan yang sesungguhnya. [10] Motivasi berprestasi adalah motivasi yang berhubungan dengan pencapaian beberapa standar kepandaian atau standar keahlian". Standar inilah yang akan dijadikan alat ukur atas motivasi tersebut.

Motivasi sangat erat hubungannya dengan tujuan yang hendak dicapai. Dalam proses belajar, motivasi sangat diperlukan oleh seseorang karena seseorang yang tidak memiliki motivasi tidak akan mungkin melakukan aktivitas belajar. [15] Motivasi adalah perubahan energi dalam diri (pribadi) seseorang yang ditandai dengan timbulnya perasaan dan reaksi untuk mencapai tujuan". Dengan adanya motivasi maka akan memberikan suatu energi positif terhadap diri seseorang untuk melakukan sesuatu. Pengembangan teori motivasi manusia menjadi enam kategori yaitu 1) tujuan afektif untuk hiburan dan ketenangan, 2) untuk memenuhi rasa ingin tahu, pemahaman, 3) Subjektif mengalami rasa spiritual harmoni atau kesatuan dengan orang, alam, atau kekuatan yang lebih besar melampaui pengalaman biasa, 4) menonjolkan diri dalam kehidupan sosial, mengalami rasa individualitas dan memperoleh dan dukungan sosial dari orang lain, 4) Integratif hubungan sosial, tanggung jawab sosial, 6) kreativitas dalam penguasaan tugas, manajemen dan keamanan.

Motivasi terbentuk atas dasar kebutuhan hidup manusia, baik kebutuhan fisiologi, kebutuhan keamanan, kebutuhan berprestasi dan sebagainya. Jika kebutuhan ini dapat dipenuhi oleh individu dengan baik maka tujuan yang diharapkan tentunya juga akan dapat tercapai dan terealiasai dengan baik juga. Motivasi berprestasi sorang siswa dalam penelitian ini diungkap melalui angket yang disebarkan kepada 95 orang siswa yang menjadi responden penelitian. Berdasarkan analisis data yang ditemukan bahwa terdapat hubungan posotif yang signifikan antara variabel 
motivasi berprestasi dengan kemampuan menyusun laporan siswa. Hal ini mejelaskan semakin tinggi motivasi berprestasi seseorang maka laporan yang dibuatnya akan memiliki kualitas yang baik pula dan begitu sebaliknya. Semakin kurang motivasi berprestasi siswa maka akan semakin rendah pula kualitas laporan yang dihasilkan.

\section{Kontribusi Kemampuan menyusun paragraf dan Motivasi berprestasi Secara Bersama Terhadap Keterampilan menulis laporan}

Hasil analisis besarnya pengaruh atau kontribusi kemampuan menyusun paragraf dan motivasi berprestasi secara bersama terhadap kemampuan menulis laporan adalah $28,1 \%$. Hasil ini menjelaskan varibel terikat berpengaruh cukup besar terhadap variabel bebas dalam penelitian ini. Hasil penelitian ini menjelaskan untuk mendapatkan laporan yang baik dua variabel bebas dalam penelitian ini harus menjasi perhatian guru. Dalam pembelajaran terutama pembelajaran praktikum laporan sangatlah penting. Laporan berarti segala sesuatu yang dilaporkan oleh pihak tertentu kepada pihak lain mengenai suatu masalah, baik secara lisan maupun tertulis, dan baik dalam kurun waktu tertentu secara rutin maupun dalam waktu tertentu saja [6].

Laporan merupakan suatu bentuk informasi yang disampaikan kepada orang lain atau suatu instansi atau badan lain dalam bentuktertulis dengan menggunakan sistematika tertentu yang menguraikan atau membahas sebuah masalah yang dihadapi disertai bukti-bukti dan fakta-fakta yang nyata. Berdasarkan pandangan itu, pengertian menulis laporan diartikan sebagai kecekatan seseorang (siswa) dalam hubungannya dengan bagaimana ia mendayagunakan semua fungsi mental/kognitifnya untuk menuangkan buah pikiran secara teratur dan terorganisasi ke dalam sebuah karangan yang berbentuk laporan. Dalam kegiatan menulis diperlukan suatu keterampilan dalam pengorganisasian ide-ide ke dalam bentuk tulisan yang runtut dan padu. Dalam tulisan tersebut harus diperhatikan kaidah-kaidah penulisannya. Tulisan yang efektif harus mengandung unsur-unsur: singkat, jelas, tepat, aliran logika lancar, serta koheren. Artinya, dalam tulisan itu tidak perlu menambahkan hal-hal di luar isi pokok tulisan, tidak mengulang-ulang yang sudah dijelaskan (redudant), tidak mempunyai arti ganda (ambiguous, dan paparan ide pokok didukung oleh penjelasan dan simpulan.

\section{A. KESIMPULAN}

Penelitian ini dapat menghasilkan kesimpulan sebagai berikut:

a. Variabel kemampuan menyusun pragraf memiliki hubungan positif yang berarti terhadap kemampuan menulis laporan. Hal ini terlihat dari perolehan hasil analisis pada hipotesis pertama, nilai korelasi antara variabel kemampuan menyusun paragraf dengan kemampuan menulis laporan adalah 0,491. Adapun kekuatan hubungannya anatara variabel kemampuan menyusun paragraf terhadap variabel kemampuan menulis laporan berada pada interval $0,30-0,49$ yang artinya memiliki hubungan mederat atau cukup tapi pasti. Besarnya sumbangan kemampuan menyusun pragraf terhadap kemampuan menulis laporan siswa adalah $24,1 \%$ dan selebihnya yaitu $75,9 \%$ dipengaruhi faktor lain diluar kemampuan menyusun pragraf. Semakin baik kemampuan menyusun pragraf seorang siswa maka akan semakin baik pula kemampuan menyusun laporannya, dan begitu sebaliknya. Berdasarkan analisis, variabel kemampuan menyusun pragraf berada pada kategori sedang.

b. Variabel motivasi berprestasi memiliki hubungan positif yang berarti terhadap variabel kemampuan menulis laporan. Berdasarkan hasil analisis pada hipotesis kedua, nilai korelasi antara variabel motivasi berprestasi dengan kemampuan menulis laporan adalah 0,386 . Adapun kekuatan hubungannya anatara variabel motivasi berprestasi terhadap variabel kemampuan menulis laporan berada pada interval 0,30 - 0,49 yang artinya memiliki hubungan mederat atau cukup tapi pasti. Besarnya sumbangan motivasi berprestasi terhadap kemampuan menulis laporan adalah $14,89 \%$ dan selebihnya yaitu $85,02 \%$ dari hasil belajar siswa dipengaruhi faktor lain. Hal ini mejelaskan semakin tinggi motivasi berprestasi seseorang maka laporan yang dibuatnya akan memiliki kualitas yang baik pula dan begitu sebaliknya. Semakin kurang motivasi berprestasi siswa maka akan semakin rendah pula kualitas laporan yang dihasilkan. Berdasarkan analisis, variabel motivasi berprestasi berada pada kategori sedang.

c. Hasil analisis variabel kemampuan menyusun pragraf dan variabel motivasi berprestasi secara bersama memiliki hubungan positif yang berarti terhadap variabel kemampuan menulis laporan. Besarnya sumbangan kemampuan menyusun pragraf dan motivasi 
berprestasi secara bersama terhadap kemampuan menulis laporan adalah $28,1 \%$. Hasil ini menjelaskan varibel bebas berpengaruh cukup besar terhadap variabel terikat dalam penelitian ini.

\section{DAfTAR Pustaka}

[1] Rubin, Joan. What the "good language learner' can teach us. New York: Mcmillan Publising Co., Inc. 1983.

[2] Suparno dan Yunus, Muhammad. Keterampilan Dasar Menulis. Jakarta: Universitas Terbuka. 2006.

[3] Nurbina, dkk. Metode Pengembangan Bahasa. Jakarta: Universitas. Terbuka. 2007.

[4] Tarigan, Henry Guntur. Menulis Sebagai Suatu Keerampilan Berbahasa. Bandung: Angkasa. 2008.

[5] Kundharu dan Slamet. Meningkatkan Keterampilan Bahasa Indonesia (Teori dan Aplikasi). Bandung. Karya Putra Darwati. 2012.

[6] Hasnun, Anwar. Pedoman Menulis untuk Siswa SMP dan SMA. Yogyakarta: Andi Offset. 2006.
[7] Widyamartaya. Kiat Menulis Deskripsi dan Narasi. Yogyakarta. Pustaka. 2005.

[8] Etty Indriati. Menulis Karya Ilmiah. Jakarta: PT. Budi Jaya. 2002.

[9] Akhadiah, Sabarti dkk. Pembinaan Kemampuan Menulis Bahasa Indonesia. Jakarta: Erlangga. 2001.

[10] Djaali. Psikologi Pendidikan. Jakarta: PT Bumi Aksara. 2012.

[11] Sumadi. Psikologi Pendidikan. Jakarta: PT. Raja Grafindo. Persada. 1993.

[12] Arikunto, S. Prosedur penelitian : Suatu Pendekatan Praktik. (Edisi. Revisi). Jakarta: Rineka Cipta. 2010.

[13] Riduwan. Metode dan tekhnik Menyusun Tesis. Bandung: Alfabeta. Atmaja. 2006.

[14] Yeti Mulyati. Keterampilan Berbahasa Indonesia SD. Jakarta: Universitas. Terbuka. 2007

[15] Hamalik, Oemar. Kurikulum dan Pembelajaran. Jakarta: Sinar Grafika. 2008. 